\title{
Economics of Sheep and Goat Rearing under Extensive, Semi- Intensive and Intensive Methods of Rearing
}

\author{
Shivakumara, C.* and Siddaraju Kiran
}

Department of Agricultural Economics, University of Agricultural Sciences, GKVK, Bengaluru, Karnataka, India

*Corresponding author: shivugarje@gmail.com (ORCID ID: 0000-0001-8851-4310)

Received: 09-04-2019 Revised: 04-07-2019 Accepted: 21-08-2019

\begin{abstract}
Sheep and goat rearing practices are followed since from the civilization of the human beings over the period of years, millions of people in the world. Sheep and goat population in southern region is consistently increasing mainly due to increase in number of keepers. Several feeding management systems are being followed. The study was carried out in Mandya and Mysuru districts of Karnataka. The random sampling technique was adopted in selecting sample for the study. 180 farmers ( 90 sheep farmers, 90 goat farmers) were selected at randomly. The results of the study revealed that overall outlay required for beginning sheep farm were, in extensive rearing ( $₹ 1,74,706)$, semi-intensive ( $₹ 2,31,243)$ and in intensive rearing ( $₹ 6,33,857)$ respectively. With respect to goat farm, extensive rearing ( $₹ 1,33,881)$, semi-intensive $(₹ 1,96,673)$ and in intensive rearing $(₹ 4,61,041)$ respectively. The total cost per annum was relatively low in goat rearing across all the rearing methods, extensive rearing ( $₹$ 1880/animal), semi-intensive rearing ( $₹$ 2355/animal) and in intensive rearing ( $₹$ 3811/animal) compared to sheep rearing, extensive rearing ( $₹$ 2060/animal), semi-intensive rearing ( $₹$ 2638/animal) and in intensive rearing ( $₹$ 3874/animal). The net return per animal was higher in goat rearing across all the rearing methods, extensive rearing ( $₹$ 1537/ animal), semi-intensive rearing ( $₹$ 2174/animal) and in intensive rearing ( $₹$ 4186/animal) compared to sheep rearing, extensive rearing ( $₹$ 1092/animal), semi-intensive rearing ( $₹$ 2020/animal) and in intensive rearing (₹ 3983/animal).
\end{abstract}

Highlights

(- This paper mainly focuses on economic aspects such as investment pattern, cost and returns of sheep and goat rearing under different rearing methods.

Keywords: Cost and returns, Rearing systems, Profitability

India is a country where, agriculture is major occupation and source of income to the majority of the people. Agriculture provides livelihood support for more than 58 percent people in the country. Since from many years, Indian agriculture is growing with the support of other allied activities such as sheep rearing, goat rearing, cow rearing, poultry rearing and so on. India has the largest livestock population in the world. Livestock sector is one of the important sources of income and employment to rural people. Both livestock and agriculture are very much dependent on each other, where livestock contributes with its manure and draught power to agriculture whereas agriculture contributes with crop residues which are major source of feed to livestock. The fact is that combination of livestock rearing and crop production enables full utilization of farm. Livestock is also important with respect to providing nutritive food to families both in rural and urban areas.

Sheep and goat rearing practices are followed since from the civilization of the human beings over the period of years, millions of people in the world are benefited from it. Europe, Asia, South America, Australia and New Zealand are the major sheep and goat rearing countries of the world. The 
livestock products have a high income elasticity of demand and are likely to grow at a faster rate. The improvement in the productivity of livestock and their raising by the poor segment of the community in rural areas can be looked up on as a major instrument, for attaining social change by improving the income of these people. This will enable them to augment their income and bring them above the poverty line and would also help in reducing the disparities between the per capita income in rural and urban sector.

\section{Production and management systems in India}

Traditionally sheep and goats were reared by people of particular communities in different regions who were either landless or small holders, illiterate, economically poor and socially backward and sheep and goats have been their main source of livelihood. Land holdings in general have negative association with sheep and goat rearing. Some medium to large herd/flocks were common in most of the villages. During last few decades, people across the income and social group have been involved in sheep and goat rearing. Herd/flocks of large size (50-300 animals) are reducing due to gradually shrinking of grazing land in almost all the regions. Sheep and goat possess an important mechanism for coping up draught, because of better flexibility and mobility as compared to crops and large ruminants in arid and semi-arid parts of southern and western regions. Major forage sources in this area are rangelands, common grazing lands and post-harvest crop field or residues (Dixit and Singh, 2014).

Small herd and flock size are reared under extensive mixed rearing systems. Sheep and goat population in southern region is consistently increasing mainly due to increase in number of keepers. Several feeding management systems are being followed in all the areas as given below.

Extensive rearing method: It's a method of grazing, the sheep and goat in the open field or entire pasture land and leaving them for the whole season. In this rearing method the cost of feeding is low. More than 80 per cent population of sheep and goats are reared under extensive system. In this method whole grasses can't be grazed efficiently. So we can preferably practice the rotational grazing method. This system includes transhumance, free range, pasture and range grazing management. It is based on low resource use and a low level of productivity. Grazing on common property resources (CPR) viz. hills, mountain, forests and waste land.

Semi-Intensive rearing method: It is a combination of limited free range grazing and feeding in stalls followed in some flocks having the limited grazing. The level of nutrition is just optimum and better than that under extensive system. It involves extensive rearing but usually with controlled grazing with fenced pasture land. It also includes of stall feeding, shelter during night and 3 to 5 hour daily grazing and browsing on pasture. The cost of feed has somewhat increased compared to extensive rearing method.

Intensive rearing method: It's a method in which sheep and goats are continuously kept under housing in confinement in which they are stall fed. Intensive operation of medium sized herd of 50 to 250 heads or more oriented towards commercial milk production goes well with this system particularly of dairy goats. This system of management requires more labour and high cash input. Sheep and goat under this system is very less in the total population. Poor adoption of production technologies is major limiting factor under intensive system. However, this has the advantage of close supervision and control over the animals. In this method, the dung is collected in one place and used as a good fertilizer. Less space is sufficient for more number of animals (Shivakumara et al. 2016).

\section{METHODOLOGY}

The study was carried out in Mandya and Mysuru districts of Karnataka. The random sampling technique was adopted in selecting sample for the study. In the first stage, two districts namely, Mandya and Mysuru were selected. In the second stage, three taluka from each district was selected based on potentiality and highest number of sheep and goat in the district. In the third stage, 180 farmers (90 sheep farmers, 90 goat farmers) were selected at randomly. The total sample size constituted 180 farmers for the study as a whole.

\section{RESULTS AND DISCUSSION}

\section{Pattern of investment under sheep and goat rearing}

The investment made for the establishment of sheep 
and goat farm includes expenditure on purchase of animals, construction of shed, fencing, equipment, electricity and water tank installation. It is evident from the Table 1 that, the investment varies for the different types of rearing methods.

In case of sheep rearing under different types of rearing, the total investment of extensive ₹ 1,74,706, semi-intensive $₹ 2,31,243$ and intensive rearing $₹ 6,33,857$, were required for establishment of sheep farm with having an average herd size of 45 in extensive, 55 in semi-intensive and 90 in intensive rearing method. However, the capital required to start goat rearing of different rearing types were $₹ 1,33,881$, ₹ $1,96,673$ and ₹ 4,61,041 under extensive, semi-intensive and extensive rearing, with having an average herd size of 38 in extensive, 50 in semiintensive and 70 in intensive rearing respectively.

In case of sheep rearing under all the different types of rearing the major capital investment was found to be in purchase of animals, extensive $(73.84 \%)$, semiintensive $(76.37 \%)$ and intensive rearing $(65.31 \%)$ respectively. Similarly, in case of goat rearing under all the different types of rearing the major capital investment was found to be in purchase of animals, extensive $(76.6 \%)$, semi-intensive $(78.30 \%)$ and intensive rearing $(67.78 \%)$ respectively.

The proportion of fixed capital investment on construction of shed was higher in sheep rearing in all the types of rearing compared to goat rearing. Whereas, proportion of investment on equipment was higher in goat rearing compared to sheep rearing, accept in case of intensive rearing. Similar pattern of investment on equipment's, electricity and water tank installation were noticed in both the category of sheep and goat rearing farms.

The comparison of investment on both sheep rearing and goat rearing revealed that fixed capital requirement for establishing sheep farm was much higher than that of goat farm.

The pattern of investment in sheep and goat rearing indicated a direct relationship between the extent of capital investment and size of the farm. The requirement of capital investment increased with the management type of rearing, size of the sheep herd and goat flock size mainly because of the increased number of sheep and goat and their price, increased requirement of land for construction of shed, fencing, equipment and other fixtures on one hand and the increased requirement of working capital on the other. The comparison of investment on method of rearing indicated that fixed capital requirement for establishing sheep and goat farm was much higher in intensive rearing method. When compared to sheep and goat rearing under all three rearing method, the investment was found to be more in case of sheep rearing.

Though the proportion of capital investment on purchase of animal was more in sheep and goat rearing, the value of animal was higher in sheep rearing compared to goat rearing in all the

Table 1: Pattern of investment in sheep and goat rearing

\begin{tabular}{cccc}
\hline Particulars & Extensive rearing & Semi-intensive rearing & Intensive rearing \\
\hline (I) Sheep ( Avg. herd size) & 45 & 55 & $\mathbf{9 0}$ \\
\hline Value of animal (₹) & $129000(73.84)$ & $176600(76.37)$ & $414000(65.31)$ \\
Shed/structure (₹) & $36433(20.85)$ & $42167(18.23)$ & $171933(27.12)$ \\
Fencing (₹) & $4215(2.41)$ & $6233(2.70)$ & $28400(4.48)$ \\
Equipment (₹) & $3180(1.82)$ & $4017(1.74)$ & $13100(2.07)$ \\
Electricity \& water tank installation (₹) & $1878(1.07)$ & $2227(0.96)$ & $6423(1.01)$ \\
Total (₹) & 174706 & 231243 & 633857 \\
\hline (II) Goat (Avg. herd size) & 38 & 50 & 70 \\
\hline Value of animal (₹) & $102600(76.64)$ & $154000(78.30)$ & $312500(67.78)$ \\
Shed/structure (₹) & $24033(17.95)$ & $51667(16.10)$ & $110333(23.93)$ \\
Fencing (₹) & $2688(2.01)$ & $5350(2.72)$ & $24733(5.36)$ \\
Equipment (₹) & $2793(2.09)$ & $3733(1.90)$ & $8326(1.81)$ \\
Electricity \& water tank installation $(₹)$ & $1766(1.32)$ & $1923(0.98)$ & $5148(1.12)$ \\
Total (₹) & 133881 & 196673 & 461041 \\
\hline
\end{tabular}

Note: 1 . Decimal values are rounded to its nearer value; 2 . Figures in parentheses indicate per cent to respective total. 
three rearing methods. The higher investment on purchase of animals mainly due to large herd size in sheep compared to goat flock size in all the three methods of rearing. Similarly, among the sheep and goat rearing, the proportion of investment on construction of shed was higher in intensive rearing compared to semi-intensive and extensive rearing. Similar trend of investment on fencing, equipment and other fixture were found.

This indicated that in intensive rearing method they have invested money on equipments like manger, drinking water tank, utensils, ropes, construction of pacca house and purchase of improved breed of sheep. The similar findings were reported by Singh et al. (2011), Deoghare and Bhatacharyya (1994) reported that, major investment was done on purchase of animals followed by construction of shed, purchase of equipments and construction of drinking water tank.

In case of intensive sheep rearing farmers have invested ₹ 1,71,933 and ₹ 13,100 on shed construction and purchase of equipment's, mainly due to larger area required for maintenance and use of modern equipment's. Similar results were reported in goat rearing at Baldeo block of Mathura district, Uttar Pradesh by Dixit et al. (2014).

In case of extensive rearing and semi-intensive rearing the family labours were enough to take care of the animals, but in case of intensive rearing the extra labour is hired who have the skills in maintaining the animals, so that they can maintain the large herd size and they can take good care of the animals.

\section{Cost and returns of sheep rearing under different rearing methods}

\subsection{Cost structure}

Cost of rearing sheep plays an important role in deciding the extent of profit. The cost structure with respect to all the three types of rearing method has been presented in the Table 2 . The results of the

Table 2: Cost and returns of sheep rearing under different rearing methods (₹/annum)

\begin{tabular}{|c|c|c|c|}
\hline Particulars & Extensive rearing & Semi-intensive rearing & Intensive rearing \\
\hline Average herd size & $(45)$ & $(55)$ & $(90)$ \\
\hline \multicolumn{4}{|l|}{ (I) Variable cost } \\
\hline Fodder and concentrates & $3063(3.3)$ & $17030(11.74)$ & $73200(21.0)$ \\
\hline Labour & $72700(78.4)$ & $95533(65.85)$ & $165767(47.55)$ \\
\hline Equipment replacement & 288(0.31) & 1523(1.05) & $4560(1.31)$ \\
\hline Veterinary care & $1653(1.78)$ & $3823(2.64)$ & $18100(5.19)$ \\
\hline Interest on variable cost & $5697(6.14)$ & 8791(6.06) & 20246(5.81) \\
\hline Sub total & 87082(93.9) & $134381(92.6)$ & $309473(88.8)$ \\
\hline \multicolumn{4}{|l|}{ (II) Fixed cost } \\
\hline Amortization cost & 3235 & 7277 & 25716 \\
\hline Depreciation on shed & 1608 & 2126 & 8799 \\
\hline \multicolumn{4}{|l|}{ Returns } \\
\hline Sale of animal & 64300 & 112067 & 420900 \\
\hline Sale of Lamb/kid & 45707 & 82433 & 189517 \\
\hline Sale of penning & 6578 & 7223 & 0 \\
\hline Sale of manure & 5408 & 19438 & 40200 \\
\hline Sale of milk & 1833 & 3242 & 8397 \\
\hline Imputed value of meat consumption & 17823 & 31600 & 47733 \\
\hline Sale of skin & 192 & 157 & 332 \\
\hline (IV) Gross returns & 141842 & 256160 & 707079 \\
\hline Returns per rupee of investment & 1.53 & 1.76 & 2.02 \\
\hline
\end{tabular}

Note: 1. Decimal values are rounded to its nearer value; 2. Values in parentheses indicate per cent to respective total. 
study revealed that variable (maintenance) cost was higher in all the three types of rearing method extensive rearing ( $₹ 87,082$ /annum), semi-intensive ( $₹ 1,34,381)$ and in intensive rearing ( $₹ 3,09,473$ ) respectively.

In case of extensive rearing, of the total variable cost, major cost component was on labour $(72,700)$, followed by cost incurred in interest on variable cost (₹ 5,697), miscellaneous expenses ( $₹ 3,680$ ), fodder and concentrates ( $₹ 3,063$ ), veterinary care ( $₹ 1,653)$ and equipment replacement (₹ 288). In case of semi-intensive rearing, of the total variable cost, major cost component was on labour (₹ 95,533), followed by cost incurred in fodder and concentrates (₹ 17,030), interest on variable cost (₹ $8,791)$, miscellaneous expenses $(₹ 7,680)$, veterinary care (₹ 3,823) and equipment replacement (₹ $1,523)$. With respect to intensive rearing, of the total variable cost, major cost component was on labour ( $₹ 1,65,767$ ), followed by cost incurred in fodder and concentrates ( $₹ 73,200)$, miscellaneous expenses ( $₹ 27,600)$, interest on variable cost (₹ $20,246)$, veterinary care (₹ 18,100$)$ and equipment replacement (₹ 4,560).

Under the fixed cost components, in all the three rearing methods, the amortization cost of the animals was found to be more, extensive rearing ( $₹$ $3,235)$, semi-intensive ( $₹ 7,277)$ and intensive rearing (₹ 25,716), followed by depreciation on shed cost, in extensive (₹ 1,608), semi-intensive (₹ 2,126) and in intensive (₹ 8,799), next to that interest on fixed cost in extensive ( $₹$ 511), semi-intensive ( $₹$ 973) and in intensive ( $₹ 3,559)$ and finally in depreciation on equipment cost in case of extensive ( $₹ 268$ ), semiintensive (₹ 324) and in intensive rearing (₹ 1,073) respectively.

\subsection{Returns}

The returns realized from sheep rearing includes sale of animals, sale of lamb, manures, milk, meat, skin and penning. The per annum total returns obtained from sheep rearing is presented in Table 2. The gross returns worked out to be higher in case of intensive rearing ( $₹ 7,07,069)$, followed by semi-intensive (₹ 2,56,160) and extensive (₹ 1,41,842) per annum.

In case of extensive rearing among the returns, the majority of the returns came from the sale of animals ( $₹$ 64,300), followed by sale of lamb (₹ $45,707)$, meat (₹ 17,823), penning ( $₹ 6,578)$, manure $(₹ 5,408)$, milk (₹ 1,833) and sale of skin (₹ 192) per annum.

In case of semi-intensive rearing among the returns, the majority of the returns came from the sale of animals (₹ 1,12,067), followed by sale of lamb (₹ $84,433)$, meat ( $₹ 31,600)$, manure ( $₹ 19,438)$, penning (₹ 7,223), milk (₹ 3,242) and sale of skin (₹ 157) per annum.

In case of intensive rearing among the returns, the majority of the returns came from the sale of animals (₹ 4,20,900), followed by sale of lamb (₹ 1,89,517), meat (₹ 47,733), manure (₹ 40,200), milk (₹ 8,397) and sale of skin (₹ 332) per annum respectively.

\section{Cost and returns of goat rearing under different rearingmethods}

\subsection{Cost structure}

The details of fixed and variable cost incurred under the three rearing types of goat is presented in Table 3. The results of the study revealed that variable (maintenance) cost was higher in all the three types of rearing method extensive rearing ( $₹$ 66,800/annum), semi-intensive ( $₹ 1,08,191$ ) and in intensive rearing $(₹ 2,41,846)$ respectively.

In case of extensive rearing, of the total variable cost, major cost component was on labour (₹ 54,967), followed by cost incurred in interest on variable cost (₹ 4,370), miscellaneous expenses ( $₹ 3,220$ ), fodder and concentrates ( $₹ 2,353)$, veterinary care $(₹ 1,650)$ and equipment replacement ( $₹ 240$ ).

In case of semi-intensive rearing, of the total variable cost, major cost component was on labour (₹ 78,167), followed by cost incurred in fodder and concentrates ( $₹ 13,500)$, interest on variable cost ( $₹$ $7,078)$, miscellaneous expenses ( $₹ 5,126)$, veterinary care (₹ 3,003) and equipment replacement (₹ 1,317).

With respect to intensive rearing, of the total variable cost, major cost component was on labour (₹ 1,35,033), followed by cost incurred infodder and concentrates (₹ 61,533), interest on variable cost (₹ 15,822), miscellaneous expenses (₹ $14,568)$, veterinary care ( $₹ 10,490)$ and equipment replacement ( $₹ 4,400)$ the results are inline with the study conducted by Reddy et al. (2018).

Under the fixed cost components, in all the three 
Table 3: Cost and returns of goat rearing under different rearing method (₹/annum)

\begin{tabular}{cccc}
\hline Particulars & Extensive rearing & Semi-intensive rearing & Intensive rearing \\
\hline Average herd size & $(38)$ & $(50)$ & $(70)$ \\
\hline (I) Variable cost & & & \\
\hline Fodder and concentrates & $2353(3.29)$ & $13500(11.47)$ & $61533(23.06)$ \\
Labour & $54967(76.94)$ & $78167(66.39)$ & $135033(50.61)$ \\
Equipment replacement & $240(0.34)$ & $1317(1.12)$ & $4400(1.65)$ \\
Veterinary care & $1650(2.31)$ & $3003(2.55)$ & $10490(3.93)$ \\
Miscellaneous expenses & $3220(4.51)$ & $5126(4.35)$ & $14568(5.46)$ \\
Interest on variable cost & $4370(6.12)$ & $7078(6.01)$ & $15822(5.93)$ \\
Sub total & $66800(93.5)$ & $108191(91.89)$ & $241846(90.7)$ \\
\hline (II) Fixed cost & & & 16061 \\
Amortization cost & 2938 & 6354 & 5932 \\
Depreciation on shed & 1056 & 2014 & 682 \\
Depreciation on equipment & 229 & 311 & 2267 \\
Interest on fixed capital & 422 & 868 & $24942(9.35)$ \\
Sub total & $4645(6.5)$ & $9547(8.11)$ & $\mathbf{2 6 6 7 8 9 ( 1 0 0 )}$ \\
\hline (III) Total cost & $71444(\mathbf{1 0 0})$ & $\mathbf{1 1 7 7 3 7 ( 1 0 0 )}$ & 335017 \\
Returns & & & 138500 \\
Sale of animal & 57850 & 95983 & 0 \\
Sale of Lamb/kid & 41630 & 73373 & 37887 \\
Sale of penning & 5476 & 7456 & 12028 \\
Sale of manure & 4048 & 16598 & 36120 \\
Sale of milk & 2517 & 4459 & 2.1 \\
\hline Sale of skin & 18213 & 28387 & $\mathbf{2 2 6 4 4 8}$ \\
\hline (IV) Gross returns & 126 & 1.92 & \\
\hline Returns per rupee of investment & 1.82 & & \\
\hline
\end{tabular}

Note: 1 . Decimal values are rounded to its nearer value; 2. Figures in parentheses indicate per cent to respective total.

rearing methods, the amortization cost of the animals was found to be more, extensive rearing ( $₹$ 2,938), semi-intensive (₹ 6,354) and intensive rearing (₹ 16,061), followed by depreciation on shed cost, in extensive ( $₹ 1,056)$, semi-intensive ( $₹ 2,014)$ and in intensive ( $₹ 5,932)$, next to that interest on fixed cost in extensive (₹ 422), semi-intensive ( $₹ 868$ ) and in intensive (₹ 2,267) and finally in depreciation on equipment cost in case of extensive (₹ 229), semi-intensive (₹ 311) and in intensive (₹ 682) respectively..

\subsection{Returns}

The returns realized from goat rearing includes sale of animals, sale of lamb, manures, milk, meat, skin and penning. The per annum total returns obtained from sheep rearing is presented in Table 3 . The gross returns worked out to be higher in case of intensive rearing ( $₹ 5,59,796)$, followed by semi-intensive ( $₹ 2,26,448)$ and extensive ( $₹ 1,29,860)$ per annum. In case of extensive rearing among the returns, the majority of the returns came from the sale of animals (₹ 57,850), followed by sale of lamb (₹ 41,630), meat (₹ 18,213), penning (₹ 5476), manure (₹ 4,048), milk (₹ 2,517) and sale of skin (₹ 126) per annum.

In case of semi-intensive rearing among the returns, the majority of the returns came from the sale of animals (₹ 95,983), followed by sale of lamb (₹ $73,373)$, meat ( $₹ 28,387)$, manure (₹ 16,598), penning (₹ 7,456), milk (₹ 4,459) and sale of skin (₹ 191) per annum.

In case of intensive rearing among the returns, the majority of the returns came from the sale of animals (₹ 3,35,017), followed by sale of lamb (₹ 1,38,500), manure ( $₹ 37,887)$, meat ( $₹ 36,120)$, milk ( $₹ 12,028)$ and sale of skin (₹ 245) per annum respectively. 
The per farm cost of sheep and goat rearing under three different method indicated that in sheep rearing the cost is more compared to goat rearing, this is due to change in the herd size and flock size of the animals and which in turn due to the larger proportion of interest on fixed capital.

However, among the rearing method, the variable cost is more in all the methods of rearing, these findings indicated that there is need to increase management efficiency, so as to reduce the goat and sheep rearing cost in order to benefit both producers and ultimate consumers. The findings of the study are in line with Dixit and Braj Mohan (2014) reported that overall cost of rearing per goat decreased with increase in flock size. Goat rearing provides financial security to the poor households and there is a need to frame and execute an all-inclusive area specific goat development programme.

Among the variable cost, major cost incurred was on labour $(76.94 \%, 66.39 \%$, and $50.61 \%$ )across all the rearing method i.e., extensive rearing, semiintensive rearing and intensive rearing, followed by fodder and concentrates $(3.29 \%, 11.47 \%$ and $23.06 \%)$ veterinary care $(2.31 \%, 2.55 \%$ and $3.93 \%)$, interest on variable cost $(6.12 \%, 6.01 \%$ and $5.93 \%)$ and replacement cost of equipment $(0.34 \%, 1.12 \%$ and $1.65 \%)$. Similar findings were observed in goat rearing in the study area. This is in accordance with the findings of Dixit et al. (2014).

It is important to mention that, interest on fixed capital was too high in sheep rearing compared to goat rearing in all the method of rearing, mainly because of larger herd size per farm, higher investment for construction of the shed, construction of drinking water tank etc. Another important component was depreciation on shed, fencing and equipment is also relatively high in sheep rearing compared to goat rearing.

The gross returns in under different rearing methods was comparatively higher in case of sheep rearing in comparison with goat rearing. It was found that in sheep and goat rearing, major component of returns was sale of the animal followed by returns obtained from the sale of lambs, sale of manure, sale of milk etc. The findings are in agreement with Suresh et al. (2008) and Tanwar and Khem Chand (2013) revealing that, in goat rearing maximum returns are obtained from sale of kids \& culled animals, followed by milk and manure.

\section{Profitability of sheep and goat rearing}

The economic aspects of sheep and goat rearing were worked out for the farmers who had maintained sheep and goat under three different types of rearing. The detailed analysis of equipment's use, cost incurred and returns obtained per animal has been presented in Table 4 .

\subsection{Sheep rearing}

In case of sheep rearing, net returns obtained per annum worked out to be ₹ 49,139 ₹ 1,11,080 and $₹ 3,58,460$ per farm in extensive, semi-intensive and intensive rearing respectively. However, net returns over variable cost was ₹ 54,760, ₹ 1,21,779 and $₹ 3,97,606$. The cost incurred and net returns realized per animal per annum were ₹ 2,060 and $₹ 1,092$ in extensive, in case of semi-intensive ₹ 2,638 and $₹ 2,020$ and in intensive rearing $₹ 3,983$ and ₹ 4,418 respectively. Similarly, net returns over variable cost found to be ₹ 1,217 per animal in extensive, ₹ 2,214 in semi-intensive and ₹ 4,418 in intensive rearing method. The profitability analysis across the rearing types indicated that the total returns increased proportionately with the method of rearing adopted. It is interesting to note that, cost per animal per annum was significantly higher in intensive (₹ 3,874) method compared to semi-intensive ( $₹ 2,638$ ) and extensive ( $₹ 2,060$ ) rearing. Further, annual net returns realized over variable cost per animal was ₹ 1,217, ₹ 2,214 and ₹ 4,418 under extensive, semi-intensive and intensive rearing respectively.

\subsection{Goat rearing}

In case of goat rearing, net returns obtained per annum worked out to be ₹ 58,416, ₹ 1,08,710 and ₹ 2,93,007 per farm in extensive, semi-intensive and intensive rearing respectively. However, net returns over variable cost was ₹ 63,060, ₹ 1,18,257 and ₹ $3,17,949$. The cost incurred and net returns realized per animal per annum were $₹ 1,880$ and $₹ 1,537$ in extensive, in case of semi-intensive ₹ 2,355 and ₹ 2,174 and in intensive rearing $₹ 3,811$ and $₹ 4,186$ respectively. Similarly, net returns over variable cost found to be ₹ 1,659 per animal in extensive, $₹ 2,365$ in semi-intensive and ₹ 4,542 in intensive 
Table 4: Profitability of sheep and goat rearing under different rearing method ( $₹ /$ annum)

\begin{tabular}{cccc}
\hline Particulars & Extensive rearing & Semi-intensive rearing & Intensive rearing \\
\hline Sheep (Avg. herd size) & 45 & 55 & 90 \\
Gross expenditure & 92703 & 145080 & 348619 \\
Gross income & 141842 & 256160 & 707079 \\
Net income & 49139 & 111080 & 358460 \\
Net Returns over variable cost & 54760 & 121779 & 397606 \\
Cost/animal & 2060 & 2638 & 3874 \\
Net return/animal & 1092 & 2020 & 3983 \\
Goat (Avg. herd size) & 1217 & 2214 & 4418 \\
Gross expenditure & 38 & 50 & 70 \\
Gross income & 71444 & 117737 & 266789 \\
Net income & 129860 & 226448 & 559796 \\
Cost/animal & 58416 & 108710 & 293007 \\
Net Returns over variable cost & 63060 & 118257 & 317949 \\
Net return/animal & 1880 & 2355 & 3811 \\
Net return over variable cost/animal & 1537 & 2174 & 4186 \\
\hline
\end{tabular}

Note: Decimal values are rounded to its nearer value.

rearing method. The profitability analysis across the rearing types indicated that the total returns increased proportionately with the method of rearing adopted.

Till recently sheep and goat rearing did not get desired phase in the rural development programmes aimed at elevating poverty. Therefore, introduction of improved technologies of sheep and goat rearing not only increases the returns but also improves the socio-economic and nutritional status of sheep and goat farmers. Keeping the importance of sheep and goat rearing for the rural poor farmers, an attempt is made to study the per animal cost and returns as well as profits in sheep and goat rearing for different rearing methods.

The per annum cost incurred per animal was comparatively low in case of goat rearing under extensive and semi-intensive compared to sheep rearing, but in case of intensive rearing the cost per animal was more in goat rearing compared to sheep rearing.

The net return per animal was more in case of semi-intensive and intensive rearing in sheep rearing compared to goat rearing because in case of semi-intensive and intensive rearing few of the farmers had reared local breeds and the hybrid breeds in sheep rearing compared to farmers in goat rearing by which they got more returns of it, but in extensive rearing it was more in goat rearing than sheep rearing, it was found that goat are more vigorous in nature and they can sustain to any diverse conditions in the environment and had capability of producing more kids and due to sale of more number of kids because of high kidding pattern of twins (around 55\%) and triplets (10\%). Similar findings were observed by Kharkar et al. (2014) and Kuralkar and Prajaktha (2015) reported kidding pattern in Barberi goats, which had 59 per cent twinning rate and 2.11 per cent triplets.

\section{CONCLUSION}

The major source of returns in sheep rearing was from sale of the animals in all the rearing methods, followed by sale of lambs, value of home consumption, penning and manure. Similarly the major source of returns in goat rearing was from sale of the animals, followed by sale of lambs, value of home consumption, penning and manure. The net return per animal was higher in goat rearing across all the rearing methods, extensive rearing (₹ 1537/animal), semi-intensive rearing (₹ 2174/ animal) and in intensive rearing ( $₹ 4186 /$ animal) compared to sheep rearing, extensive rearing ( $₹$ 1092/animal), semi-intensive rearing ( $₹$ 2020/animal) and in intensive rearing ( $₹$ 3983/animal). 


\section{ACKNOWLEDGMENTS}

Authors acknowledge Mr. Honnaiah, Associate professor (Rtrd) for his valuable suggestions during preparation of this article.

\section{REFERENCES}

Deoghare, P.R. and Bhattacharyya, N.K. 1994. Economics of Jamunapari goat rearing in Etawah district of Uttar Pradesh. Indian J. Anm. Sci., 64: 1390-1393.

Dixit, A.K. and Braj Mohan. 2014. Economics of goat production in Mathura district of Uttar Pradesh. The Indian Journal of Small Ruminants, 20(2): 96-98.

Dixit, A.K., Singh, M.K. and Rai. 2014. Goat production and marketing in India: Opportunities and challenges. Indian Society for Sheep and Goat Production and Utilization, Conference Issue: pp. 81-92.

Dixit, A.K. and Singh, M.K. 2014. Economic analysis of goat rearing under field conditions of Bundelkhand region, The Indian Journal of Small Ruminants., 20(2): 165-168.

Kakar, Z., Ali, I., Kausarzeb, Shah, Z.A., Haq, I.U., Rafiuallah, Hussain, T. and Khan, S. 2013. Production patterns of sheep and goats in district Qila Abdullah (Balochistan). The Journal of Animal and Plant Sciences, 23(1): 35-38.
Kharkar Kranti, Kuralkar, S.V. and Kuralkar Prajakta. 2014. Growth, production and reproduction performance of Berari goats in their native tract. Indian Journal of Small Ruminants, 5(3): 115-122.

Shivakumara, C., Reddy, B.S., Satihal, D.G. and Suresh, S.P. 2016. Production performance and mortality rate under sheep and goat farming in Karnataka. J. Exp. Zool. India, 19(1): 1481-1484.

Reddy, B.S., Shivakumara, C. and Dixit, A.K. 2018. Small Ruminant Farming in Karnataka (India): A Pathway of Sustainable livelihood security and enhancing farmer's income, Paper presented in: International Association of Agricultural Economists (IAAE) Conference, July 28-August 2, 2018, Vancouver, British Columbia, pp. 288.

Singh, Satyendra Pal, Singh, A.K. and Prasad, R. 2011. Economics of goat rearing in Agra district of Uttar Pradesh. Indian Res. J. Ext. Edu., 11: 3-5.

Suresh, A., Gupta, D.C. and Mann, J.S. 2008. Returns and economic efficiency of sheep rearing in semi-arid regions: A study in Rajasthan, Agric. Econ. Res. Rev., 21: 227-234.

Tanwar, P.S. and Chand Khem. 2013. Economic analysis of goat rearing under field conditions in Rajasthan. Indian Journal of Small Ruminants, 19: 75-78. 
